\title{
ANALISIS KUALITAS PELAYANAN UJI KIR TERHADAP KEPUASAN MASYARAKAT PENGGUNA JASA KIR DI DINAS PERHUBUNGAN KOTA KEDIRI
}

\author{
Quality Analysis Of KIR Service On User Satisfaction At The Transportation Agency Of Kediri \\ City
}

Agung Santoso ${ }^{1}$

${ }^{1}$ Magister Ilmu Administrasi Universitas Kadiri

\begin{abstract}
Abstrak
Pelayanan publik yang diselenggarakan oleh organisasi publik merupakan salah satu perwujudan dari fungsi aparatur pemerintah negara sebagai abdi masyarakat. Pelayanan publik dimaksudkan untuk mensejahterakan masyarakat. Kondisi masyarakat yang mengalami perkembangan dinamis, Tingkat kehidupan masyarakat yang semakin baik, mengakibatkan masyarakat semakin sadar akan apa yang menjadi hak dan kewajibannya sebagai warga negara dalam hidup bermasyarakat, mengajukan tuntutan, keinginan dan aspirasinya kepada pemerintah. Tujuan dari penelitian ini adalah sebagai berikut: 1) Untuk mengetahui kualitas pelayanan uji KIR di Dinas Perhubungan (Dishub) Kota Kediri?, 2) Untuk mengetahui kepuasan masyarakat pengguna jasa KIR di Dinas Perhubungan (Dishub) Kota Kediri?,3)Untuk menganalisis pengaruh kualitas pelayanan uji KIR terhadap kepuasan masyarakat pengguna jasa KIR di Dinas Perhubungan (Dishub) Kota Kediri? Penelitian ini menggunakan rancangan atau desain penelitian kuantitatif. Penelitian ini terdiri dari dua variabel, yaitu variabel independen penelitian ini adalah kualitas pelayanan sedangkan variabel dependen penelitian adalah kepuasan masyarakat pengguna jasa uji kendaraan bermotor, pengambilan data dengan membagikan kuesioner kepada responden. Berdasarkan hasil penelitian seperti yang telah dipaparkan dalam bab sebelumnya, maka dapat diambil suatu kesimpulan berikut ini :1) Berdasarkan hasil penelitian telah terbukti bahwa kualitas pelayanan uji KIR di Dinas Perhubungan (Dishub) Kota Kediri sudah baik, pelayanan pegawai, fasilitas serta alat-alat pendukung yang digunakan dalam pengujian sudah lengkap dan modern. 2) Berdasarkan hasil analisis telah terbukti bahwa Tingkat kepuasan masyarakat pengguna jasa KIR di Dinas Perhubungan (Dishub) Kota Kediri cukup tinggi. 3) Ada pengaruh yang signifikan variabel kualitas pelayanan terhadap kepuasan masyrakat pengguna jasa layana uji kir di dinas perhubungan Kota Kediri, variabel kualitas pelayanan berpengaruh sebesar 78,6\% terhadap kepuasan masyarakat pengguna layanan jasa tersebut.
\end{abstract}

Kata Kunci: kualitas pelayanan; kepuasan masyarakat; jasa KIR

\begin{abstract}
Public services organized by public organizations are one manifestation of functions of the state government apparatus as civil servants. Public services are intended to prosper the community. The condition of people who experience dynamic development, the better level of community life, resulting in people becoming more aware of what their rights and obligations are as citizens in living in the community, proposing their demands, desires, and aspirations to the government. The purpose of this study are as follows: 1) To determine the service quality of KIR test at the Department of Transportation (Dishub) of Kediri City? 2) To find out the satisfaction of KIR service users in the Department of Transportation (Dishub) of Kediri City?, 3) To analyze the influence Kir test service quality to the satisfaction of KIR service users in the Kediri City Transportation Agency (Dishub)? This study uses quantitative research designs. This study consists of two variables, namely the independent variable of this study is the quality of service while the dependent variable of the study is the satisfaction of the users of mobile vehicle testing services, data collection by distributing questionnaires to respondents. Based on the results of the research. The following conclusions can be drawn: 1) Based on the results of the investigation it has been proven that the quality of service of the KIR test at the Kediri City Transportation Agency (Dishub) is good, service employees, facilities and tools the support used in the test is complete and modern. 2) Based on the results of the analysis it has been proven that the level of satisfaction of KIR service users in the Kediri City Transportation Agency (Dishub) is quite high. 3) There is a significant effect of service
\end{abstract}


quality variables on community satisfaction of test service users in the city of Kediri, service quality variables have an impact of $78.6 \%$ on the achievement of the service user community

Keywords: service quality; user satisfication; KIR service

\section{A. PENDAHULUAN}

Perkembangan informasi dan komunikasi yang pesat menuntut kinerja lembaga pemerintah juga semakin baik dalam memberikan pelayanan publik yang dibutuhkan oleh masyarakat, dikarenakan masyarakat semakin kritis terhadap kinerja publik pemerintahan, sehingga abdi negara saat ini dituntut untuk lebih responsif, karena tidak jamannya pemerintahan yang bekerja lamban dan cenderung tidak professional dalam melaksanakan tugas-tugas birokrasi dalam kewenangannya.

Masyarakat saat ini memiliki ruang untuk berbicara di tempat publik, jika ada pelayanan yang kurang memuaskan sedang atau sudah dialaminya. Fenomena yang sering terjadi dan sering kita jumpai di media elektronik maupun media massa yaitu mengenai ketidakpuasan masyarakat terhadap pelayanan publik, banyak hal yang mempengaruhi pelayanan yang diberikan tidak optimal, pemerintah terus berupaya memperbaiki kualitas pelayanan yang diberikan agar dapat meningkatkan kepuasan pelanggan, mulai dari perbaikan sistem keluhan pelanggan serta inovasi-inovasi dalam penyelenggaraan pelayanan, sehingga semakin memudahkan masyarakat dalam memperoleh pelayanan tanpa harus ada tatap muka secara langsung.

Penelitian ini dianggap penting dikarenakan, apabila pelayanan pengujian kendaraan bermotor yang diselenggarakan pemerintah tidak dilakukan dengan baik atau semakin tidak memuaskan pelanggan sebagai penerima pelayanan dikhawatirkan nantinya pelanggan akan menuntut agar pengujian kendaraan bermotor dilakukan oleh pihak swasta sesuai dengan Undang-Undang Nomor 22 Tahun 2009 Tentang Lalu Lintas dan Angkutan Jalan Pasal 53 Nomor 3 yang menyatakan bahwa: Kegiatan pemeriksaan dan pengujian fisik Kendaraan Bermotor sebagaimana dimaksud pada ayat (2) huruf a dilaksanakan oleh: a). unit pelaksana pengujian pemerintah kabupaten/kota; b).unit pelaksana agen tunggal pemegang merek yang mendapat izin dari Pemerintah; atau c). unit pelaksana pengujian swasta yang mendapatkan izin dari Pemerintah.

Kepuasan masyarakat merupakan kunci atau ujung tombak bagi keberhasilan penyelenggaraan pelayanan publik. Kepuasan telah memperoleh perhatian dominan dan menjadi faktor strategis dalam pelayanan. Wilkie dalam Tjiptono, mendefinisikan kepuasan masyarakat atau pelanggan sebagai tanggapan emosional pada evaluasi terhadap pengalaman konsumsi suatu produk dan jasa. Oleh karena itu, pihak penyelenggaraan pelayanan publik harus benar-benar mengerti dan memahami apa kebutuhan masyarakat. Pengelola penyelenggaraan pelayanan publik harus mengetahui apakah mutu layanan yang diberikan sudah memenuhi standar dan sesuai dengan keinginkan masyarakat, atau justru sebaliknya.

Seperti kondisi di Dinas Perhubungan Kota Kediri yang menempatkan pelayanan pada transportasi umum sebagai bagian dari kebutuhan masyarakat yang tidak dapat ditawartawar lagi. Kesadaran masyarakat terhadap hak dan kewajibannya untuk memperoleh berbagai jenis pelayanan, termasuk bidang transportasi, pelayanan publik transportasi merupakan tantangan dan tanggung jawab yang besar bagi Dinas Perhubungan dalam menciptakan keterbukaan dan kemudahan bidang transportasi serta kemudahan mengakses berbagai informasi melalui media yang ada. Dinas Perhubungan Kota Kediri berusaha menciptakan sistem transportasi yang aman, lancar dan tertib agar masyarakat merasa nyaman berkendaraan. Meningkatkan penyediaan sarana, prasarana dan fasilitas perhubungan untuk mengurangi kecelakaan lalu lintas dan menghindarkan masyarakat dari kesesatan dalam perjalanan. Meningkatkan kualitas pelayanan Angkutan Umum dengan memberikan pemahaman pada Kru Angkutan tentang Peraturan/Undangundang Lalu Lintas. Menciptakan masyarakat Kota Kediri yang komunikatif sehingga dapat terjalin hubungan yang sinergi dengan Pemerintah Kota Kediri untuk meningkatkan partisipasi masyarakat dalam keselamatan dalam berkendara di jalan raya.

Berdasarkan uraian fakta dan paparan teori di atas yang kemudian melatarbelakangi penulis untuk mengambil judul Analisis Kualitas Pelayanan Uji KIR Terhadap Kepuasan Masyarakat Pengguna Jasa KIR di Dinas Perhubungan Kota Kediri.

\section{B. METODE PENELITIAN}

Sesuai dengan tujuan penelitian yang telah dikemukakan di depan, maka penelitian ini menggunakan rancangan atau desain penelitian kuantitatif. Penelitian ini terdiri dari dua variabel, yaitu variabel independen penelitian ini adalah 
kualitas pelayanan sedangkan variabel dependen penelitian adalah kepuasan masyarakat pengguna jasa uji kendaraan bermotor, pengambilan data dengan membagikan kuesioner kepada responden sehingga didapatkan data berupa angka yang ditabulasikan kedalam bentuk skor, untuk mengetahui indeks kepuasan masyarakat dari pelayanan di unit pelaksana teknis uji kendaraan bermotor Dinas Perhubungan Kota Kediri.

Populasi dalam penelitian ini adalah pengguna layanan uji KIR di Dinas Perhubungan Kota Kediri, untuk jangka waktu uji selama bulan september 2016. Dengan jumlah populasi lebih dari 1.250 pengguna jasa uji KIR. Sedangkan sampel diambil secara accidental sampling, yaitu masyarakat (pengguna layanan uji KIR) yang datang ke Dinas Perhubungan Kota Kediri saat ditemui oleh peneliti. Sampel yang dijadikan responden dalam penelitian ini sebanyak 150 responden.Sampel penelitian ini adalah sebagian populasi pengguna layanan uji KIR di Dinas Perhubungan Kota Kediri selama bulan September 2016 sebanyak 150 sampel. Jumlah responden ini adalah sesuai dengan jumlah responden yang dipersyaratkan dalam kepmen PAN No. 25 tahun 2004.

Instrumen penelitian yang akan digunakan adalah kuesioner. Kuesioner penelitian kemudian dibagi kepada 150 orang responden dibuat dalam bentuk rating scale sesuai dengan skala pengukuran yang dipakai. Jumlah responden ini adalah sesuai dengan jumlah responden yang dipersyaratkan dalam kepmen PAN No. 25 tahun 2004.

Analisis regresi pada dasarnya adalah studi mengenai ketergantungan variabel dependen (terikat) dengan satu atau lebih variabel independen (variabel penjelas/bebas), dengan tujuan untuk mengestimasi dan/atau memprediksi rata-rata populasi atau nilai-nilai variabel dependen berdasarkan nilai variabel independen yang diketahui (Ghozali, 2005). Persamaan regresi di dalam penelitian ini untuk mengetahui seberapa besar pengaruh variabel bebas yaitu kualitas pelayanan terhadap kepuasan masyarakat pengguna jasa uji kendaraan bermotor (KIR). Adapun model hubungan antar variabel dapat disusun dalam persamaan di bawah ini :

Persamaan : $\mathrm{Y}=\beta 0+\beta 1 \mathrm{X}$

Keterangan :

Y: Kepuasan masyarakat pengguna jasa KIR

\section{$\beta 0$ : Konstanta}

X: Variabel kualitas pelayanan

Uji-t dilakukan untuk mengetahui seberapa jauh varibel independen $(X)$ mempengaruhi variabel dependennya $(\mathrm{Y})$, yaitu seberapa jauh kualitas pelayanan di Dinas Perhubungan mempengaruhi kepuasan masyarakat pengguna jasa uji kendaraan. Dengan norma keputusan jika nilai t-hitung lebih besar dari nilai t-tabel maka variabel $X$ berpengaruh signifikan terhadap varibel $Y$, begitupula sebaliknya jika nilai thitung lebih kecil dari nilai $t$ tabel maka variabel $X$ tidak berpengaruh terhadap variabel $\mathrm{Y}$.

\section{PEMBAHASAN}

Berdasark analisis menunjukkan bahwa variabel kualitas pelayanan $(X)$ menghasilkan $t$ hitung sebesar $15,448<$ nilai $\mathrm{t}$ tabel 1,65508 sedangkan nilai sig. $>\bar{\alpha}$ yaitu $0,000<0,05$ dengan demikian maka $\mathrm{H} 0$ ditolak dan $\mathrm{H} 1$ diterima. Maka dapat disimpulkan bahwa variabel kualitas pelayanan mempunyai pengaruh yang signifikan terhadap kepuasan masyarakat pengguna jasa layanan uji kir di Dinas Perhubungan Kota Kediri. Penelitian ini juga menemukan fakta bahwa besar pengaruh variabel kualitas pelayanan di unit uji kendaraan terhadap kepuasan masyarakat sebesar 78,6\%. selanjutnya penelitian ini juga mendapatkan nilai $\mathrm{R}$ Square sebesar 0,617 yang bermakna bahwa kemampuan variabel kualitas pelayanan (X) dalam ketepatan memprediksi variasi variabel kepuasan masyarakat pengguna jasa uji kir di Dinas Perhubungan Kota Kediri sebesar 61,7\%, sedangkan sisanya 38,3\% dipengaruhi oleh variabel lain yang pada penelitian ini variabel tersebut tidak diteliti.

Temuan di atas sejalan dengan pendapat dari Moenir agar pelayanan dapat memuaskan orang atau kelompok orang lain yang di layani, maka pelaku yang bertugas melayani harus memenuhi empat kriteria pokok, yaitu : 1 . Tingkah laku yang sopan; 2. Cara menyampaikan sesuatu yang berkaitan dengan apa yang seharusnya diterima oleh orang yang bersangkutan; 3. Waktu menyampaikan yang tepat; 4. Keramah-tamahan. Kriteria tersebut rupanya sudah diterapkan di unit kendaraan bermotor Dinas Perhubungan Kota Kediri, pelayanan yang prima dengan prosedur yang jelas merupakan visi yang ingin dicapai pihak Dinas Perhubungan demi memberikan kepuasan kepada masyarakat pengguna layanan. Tentu saja dalam pelayanan yang diberikan tidak serta merta bisa memberikan kepuasan kepada semua masyarakat pengguna layanan, ada kekurangan disana-sini seperti terjadinya kemolorotan waktu 
estimasi pengujian karena ada banyak antrian misalnya, atau ruang tunggu yang kurang karena membludaknya jumlah masyarakat pengguna layanan memang masih terjadi, di masa depan diperlukan penyempurnaan dalam pelayanan tersebut tentunya.

Menjadi sebuah lembaga pelayanan publik yang akuntabel, transparan serta efisien dalam memberikan jasa uji kendaraan memang perlu penyempurnaan di masa yang akan datang, tingkat kepuasan yang sudah dicapai oleh unit uji kendaraan bermotor Dinas Perhubungan Kota Kediri sebesar 78,6\% patut mendapatkan apresiasi atas pencapaian yang diraih. Sehingga di masa depan perlu peningkatan kepuasan masyarakat dalam pelayanan uji kendaraan bermotor di Kota Kediri, kepuasan masyarakat menjadikan lembaga publik ini menjadi tolak ukur dalam kinerja aparat pemerintahan yang efisien dan akuntabel.

\section{E. KESIMPULAN DAN REKOMENDASI}

Berdasarkan hasil penelitian seperti yang telah dipaparkan dalam bab sebelumnya, maka dapat diambil suatu kesimpulan berikut ini : Berdasarkan hasil penelitian yang telah dilakukan, maka terbukti bahwa fasilitas serta alat pendukung yang digunakan Dinas Perhubungan Kota Kediri dalam pengujian sudah lengkap dan modern sesuai dengan standart dan ketentuan perudang-udangan Nomor 25 tahun 2009 tentang Pelayanan Publik bahwa komponen standart pelayanan harus memenuhi Sarana, prasarana, dan/atau fasilitas. Peralatan yang dimiliki diantaranya sebagai berikut:

Jenis Peralatan dan Sarana Uji Standart Menurut Perundang-udangan Kondisi Riil

$\begin{array}{lcc}\text { Diesel smoke tester } & \text { Ada } & \text { Baik } \\ \text { Emision analyser tester } & \text { Ada } & \text { Baik } \\ \text { Pit life } & \text { Ada } & \text { Baik } \\ \text { Side slip tester } & \text { Ada } & \text { Baik } \\ \text { Axie load } & \text { Ada } & \text { Baik } \\ \text { Head light tester } & \text { Ada } & \text { Baik } \\ \text { Sound level meter } & \text { Ada } & \text { Baik } \\ \text { Brake tester } & \text { Ada } & \text { Baik } \\ \text { Boogie roll } & \text { Ada } & \text { Baik } \\ \text { Spedometer tester } & \text { Ada } & \text { Baik }\end{array}$

Generator set

Ada

Baik

Air compresso

Ada Baik

Berdasarkan hasil penelitian maka telah terbukti bahwa Tingkat kepuasan masyarakat pengguna jasa KIR di Dinas Perhubungan (Dishub) Kota Kediri cukup tinggi, yaitu sebanyak $71,67 \%$ menyatakan puas. Ada pengaruh yang signifikan variabel kualitas pelayanan terhadap kepuasan masyrakat pengguna jasa layanan uji kir di Dinas Perhubungan Kota Kediri. Hal tersebut dibuktikan dengan hasil hitung $\mathrm{t}$ hitung sebesar $15,448<$ nilai $t$ tabel 1,65508 sedangkan nilai sig. $>\bar{\alpha}$ yaitu $0,000<0,05$ dengan demikian maka $\mathrm{H} 0$ ditolak dan H1 diterima. Penelitian ini menemukan fakta pengaruh variabel kualitas pelayanan terhadap kepuasan masyarakat sebesar $78,6 \%$. Selanjutnya penelitian ini juga mendapatkan nilai R Square sebesar 0,617 yang bermakna bahwa kemampuan variabel kualitas pelayanan (X) dalam ketepatan memprediksi variasi variabel kepuasan masyarakat pengguna jasa uji kir di Dinas Perhubungan Kota Kediri sebesar 61,7\%, sedangkan sisanya 38,3\% dipengaruhi oleh variabel lain yang pada penelitian ini variabel tersebut tidak diteliti.

\section{F. REFERENSI}

Moenir, A. S. 2006. Manajemen Pelayanan Umum di Indonesia. Bumi Aksara. Jakarta.

Tjiptono, Fandy, 2004. Manajemen Jasa, Cetkan ketiga. Penerbit Andi.Yogyakarta.

Tjiptono, Fandy., 2007. Prinsip-prinsip Total Quality (TQS). Penerbit ANDI.Yogyakarta.

Undang-Undang Nomor 22 Tahun 2009 tentang Lalu Lintas dan Angkutan Jalan

Undang-undang Nomor 34 Tahun 2000 tentang Pajak dan Retribusi Daerah.

Undang-undang Nomor 32 Tahun 2004 tentang Pemerintahan Daerah, merupakan Revisi atas UU No.22 Tahun 1999. 


\section{MEDIA505IAN}

Jurnal Ilmu Sosial dan Ilmu Administrasi Negara Vol. 2 No. 1 